\title{
18F-NaF Positive Bone Metastases of Non I8F-FDG Avid Mucinous Gastric Cancer
}

\author{
I8F-FDG Negatif Musinöz Mide Kanserinin I8F-NaF Pozitif Kemik MetastazI
}

\author{
Çiğdem Soydal, Elgin Özkan, Özlem Nuriye Küçük, Metin Kemal Kır \\ Ankara University Faculty of Medicine, Department of Nuclear Medicine, Ankara, Turkey
}

\begin{abstract}
Detection of gastric cancer bone metastasis is crucial since its presence is an independent prognostic factor. In this case report, we would like to present $18 \mathrm{~F}-\mathrm{NaF}$ positive bone metastases of non 18F-FDG avid gastric mucinous cancer.

Keywords: Gastric cancer, bone metastasis, positron emission tomography/computed tomography
\end{abstract}

Öz

Mide kanserinin kemik metastazının saptanması bağımsız bir prognostik faktör olması nedeni ile kritiktir. Bu olguda $18 \mathrm{~F}-\mathrm{FDG}$ tutulumu izlenmeyen müsinöz mide kanserine ait 18F-NaF pozitif kemik metastazlarını sunmak istedik.

Anahtar kelimeler: Mide kanseri, kemik metastazı, positron emisyon tomografisi/bilgisayarlı tomografi

\section{Introduction}

Gastric cancer could metastasize to different sites prior to diagnosis. The rate of bone metastasis has been reported as $1 \%$ to $20 \%$ for gastric cancer $(1,2,3)$. Detection of gastric cancer bone metastasis is crucial since its presence is an independent prognostic factor (4). In this report, we would like to present a case with gastric cancer bone metastases that could not be shown by 18F-FDG positron emission tomography/computed tomography (PET/CT).

\section{Case Report}

A 58 years old female patient with histopahologically proven gastric mucinous adenocarcinoma was referred to Ankara University Medical Faculty Department of Nuclear Medicine with a request of $18 \mathrm{~F}-\mathrm{FDG}$ PET/CT for staging. The whole body 18F-FDG PET/CT imaging was performed approximately 1 hour after intravenous injection of 370 $\mathrm{MBq}$ 18F-FDG. PET/CT images were acquired with GE
Discovery ST PET/CT scanner (General Electric, Milwaukee, Wisconsin, USA). Emission PET images were reconstructed with non-contrast $\mathrm{CT}$ data for attenuation correction. In the evaluation of 18F-FDG PET/CT images, there was no pathological uptake in the stomach and whole body except diffuse increase in gastric wall thickness (Figure 1). Multiple sclerotic bone lesions were detected in axial CT images (Figure 2). An 18F-NaF PET/CT was performed to exclude bone metastases. 18F-NaF PET/CT images were obtained by the same scanner and parameters with CT, approximately 30 minutes after intravenous injection of $135 \mathrm{MBq}$ 18F-NaF from vertex to feet. Intense 18F-NaF uptake was seen in multiple sclerotic bone lesions in the vertebral column, sternum, ribs, scalp and both scapula (Figure 3).

\section{Literature Review and Discussion}

18F-FDG PET/CT is a hybrid imaging modality used in the staging of several cancers. However, the role of $18 \mathrm{~F}-\mathrm{FDG}$

Address for Correspondence: Çiğdem Soydal MD, Ankara University Faculty of Medicine, Department of Nuclear Medicine, Ankara, Turkey Phone: +90 3125956732 E-mail: csoydal@yahoo.com Received: 14.09.2013 Accepted: 28.01.2014 
PET/CT in the detection of bone metastases of gastric cancer is controversial $(4,5,6,7,8,9,10)$. No algorithm has yet been defined to detect bone metastases of gastric cancer.

In our case, bone metastases of gastric cancer could not be shown by 18F-FDG PET/CT. In our case, we suspected bone metastases of gastric cancer in spite of lack of $18 \mathrm{~F}-\mathrm{FDG}$ uptake, because absence of uptake in the primary tumor was probably related to the mucinous component and sclerotic pattern of bone lesions. For

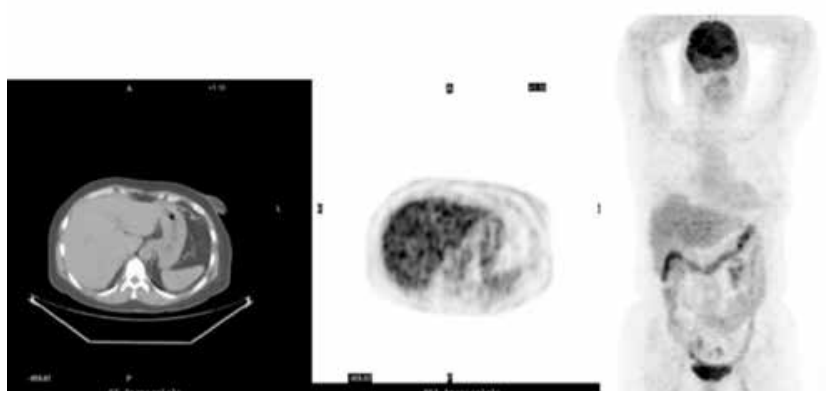

Figure 1. Axial computed tomography, PET and whole body maximum intensity projection 18F-FDG positron emission tomography/computed tomography images of the patient. There was no pathological uptake in the stomach or entire body

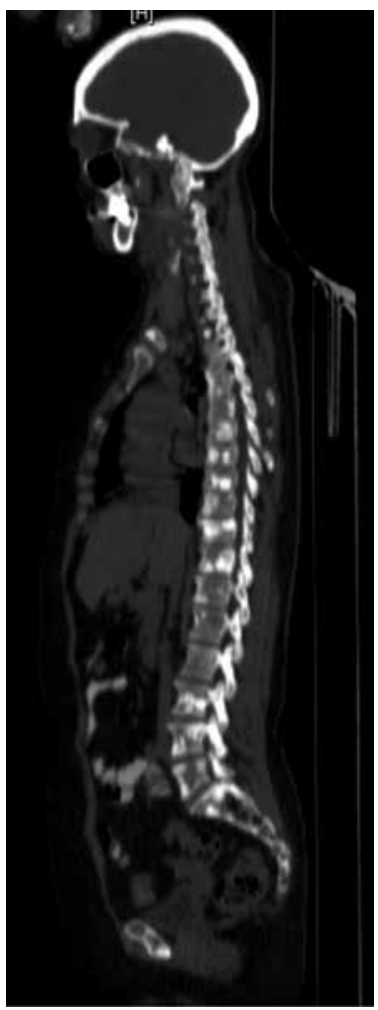

Figure 2. Sagittal computed tomography image of the patient. Multiple sclerotic lesions were seen in the entire skeleton these reasons an $18 \mathrm{~F}-\mathrm{NaF}$ PET/CT was performed to evaluate bone lesions, and 18F-NaF PET/CT confirmed bone metastases.

Conventional staging modalities such as bone scintigraphy are more valuable especially in patients with non 18F-FDG avid tumors. Various imaging methods including 18F-FDG PET/CT, whole body bone scintigraphy, magnetic resonance imaging and $C T$ could be utilized to detect bone metastases. Tc-99m MDP bone scintigraphy is the traditional method to evaluate bone metastases of several cancers with low cost (5). The poor spatial resolution and longer duration of the examination result in limitations to bone scintigraphy. High quality images of the skeleton can be obtained within one hour after intravenous injection of $18 \mathrm{~F}-\mathrm{NaF}$ (6). In a recent study, lagaru et al. (7) have reported that $18 \mathrm{~F}-\mathrm{NaF}$ PET/CT is superior to 18F-FDG PET/CT in the detection of bone metastases. An advantage of combined PET/CT systems is that they provide skeletal system evaluation with highly sensitive and specific images (8). During evaluation of 18F-FDG PET/CT images, skeletal lesions could be seen in $\mathrm{CT}$ series and these lesions could be evaluated by other methods to show bone metastases. In patients with non 18F-FDG avid tumors that could often metastasize to bone, CT series should be carefully evaluated to search bone lesions.

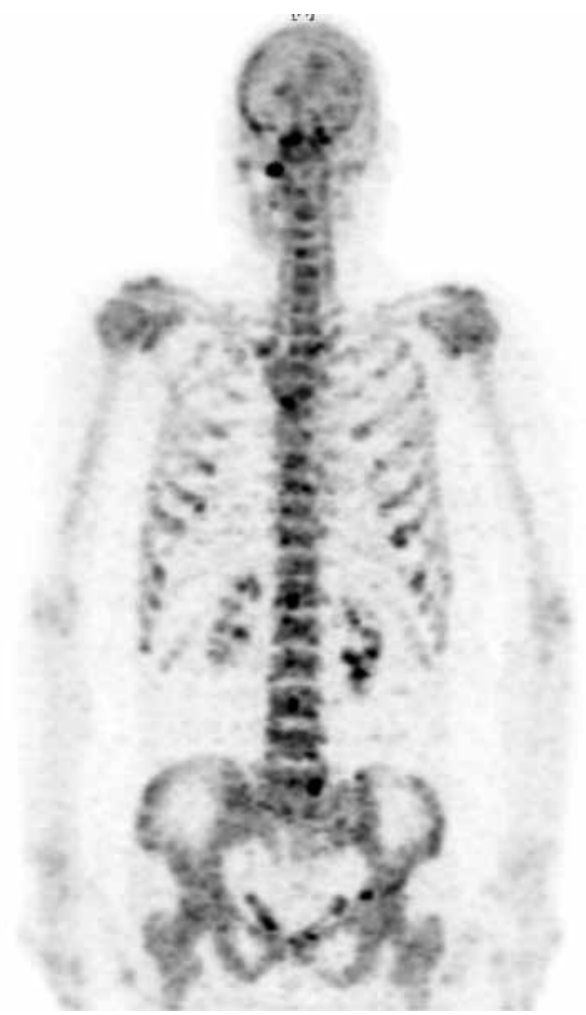

Figure 3. Whole body maximum intensity projection ${ }^{18} \mathrm{~F}-\mathrm{NaF}$ positron emission tomography/computed tomography image of the patient. Intense $18 \mathrm{~F}-\mathrm{NaF}$ uptake was seen in sclerotic bone lesions 
Informed Consent: It was taken, Concept: Çiğdem Soydal, Design: Çiğdem Soydal, Data Collection or Processing: Elgin Özkan, Analysis or Interpretation: Çiğdem Soydal, Özlem Nuriye Küçük, Literature Search: Çiğdem Soydal, Metin Kemal Kır, Writing: Çiğdem Soydal, Peer-review: Externally peer-reviewed, Conflict of Interest: No conflict of interest was declared by the authors, Financial Disclosure: The authors declared that this study has received no financial support.

\section{References}

1. Noda N, Sano T, Shirao K, Ono H, Katai H, Sasako M, Maruyama K. A case of bone marrow recurrence from gastric carcinoma after a nine-year disease-free interval. Jpn J Clin Oncol 1996;26:472-475.

2. Yoshikawa K, Kitaoka H. Bone metastasis of gastric cancer. Jpn J Surg 1983;13:173-176.

3. Nishidoi H, Koga S. [Clinicopathological study of gastric cancer with bone metastasis]. Gan To Kagaku Ryoho 1987;14:1717-1722.

4. Yoshioka T, Yamaguchi K, Kubota K, Saginoya T, Yamazaki T, Ido T, Yamaura G, Takahashi H, Fukuda H, Kanamaru R. Evaluation of $18 \mathrm{~F}-\mathrm{FDG}$ PET in patients with advanced, metastatic, or recurrent gastric cancer. J Nucl Med 2003;44:690-699.
5. Savelli G, Maffioli L, Maccauro M, De Deckere E, Bombardieri E. Bone scintigraphy and the added value of SPECT (single photon emission tomography) in detecting skeletal lesions. Q J Nucl Med 2001;45:2737.

6. Grant FD, Fahey FH, Packard AB, Davis RT, Alavi A, Treves ST. Skeletal PET with 18F-fluoride: applying new technology to an old tracer. J Nucl Med 2008;49:68-78.

7. lagaru A, Young P, Mittra E, Dick DW, Herfkens R, Gambhir SS. Pilot retrospective evaluation of Tc-99m-MDP scintigraphy, 18F NaF PET/ CT, 18F FDG PET/CT and whole-body MRI for detection of skeletal metastases. Clin Nucl Med 2013;38:290-296.

8. Even-Sapir E, Metser U, Flusser G, Zuriel L, Kollender Y, Lerman H, Lievshitz G, Ron I, Mishani E. Assessment of malignant skeletal disease: initial experience with 18F-fluoride PET/CT and comparison between 18F-fluoride PET and 18F-fluoride PET/CT. J Nucl Med 2004;45:272-278.

9. Hillner BE, Siegel BA, Liu D, Shields AF, Gareen IF, Hanna L, Stine SH, Coleman RE. Impact of positron emission tomography/computed tomography and positron emission tomography (PET) alone on expected management of patients with cancer: initial results from the National Oncologic PET Registry. J Clin Oncol 2008;26:21552161.

10. Nakai T, Okuyama C, Kubota T, Ushijima Y, Nishimura T. FDG-PET in a case of multiple bone metastases of gastric cancer. Ann Nucl Med 2005;19:51-54. 